\title{
The hydrolysis of geminal ethers: a kinetic appraisal of orthoesters and ketals
}

\author{
Sonia L. Repetto ${ }^{1}$, James F. Costello ${ }^{*}$, Craig P. Butts ${ }^{2}$, Joseph K. W. Lam ${ }^{3}$ \\ and Norman M. Ratcliffe ${ }^{1}$
}

\author{
Full Research Paper \\ Address: \\ ${ }^{1}$ Faculty of Applied Sciences, University of the West of England, \\ Bristol, BS16 1QY, UK, ${ }^{2}$ School of Chemistry, University of Bristol, \\ Bristol, BS8 1TS, UK and ${ }^{3}$ Airbus Operations Ltd., Filton, Bristol, \\ BS34 7PA, UK \\ Email: \\ James F. Costello* - James.Costello@uwe.ac.uk \\ * Corresponding author \\ Keywords: \\ FDIl; geminal ethers; kinetics
}

Beilstein J. Org. Chem. 2016, 12, 1467-1475.

doi:10.3762/bjoc. 12.143

Received: 12 April 2016

Accepted: 23 June 2016

Published: 15 July 2016

Associate Editor: J. A. Murphy

(c) 2016 Repetto et al.; licensee Beilstein-Institut. License and terms: see end of document.

\begin{abstract}
A novel approach to protecting jet fuel against the effects of water contamination is predicated upon the coupling of the rapid hydrolysis reactions of lipophilic cyclic geminal ethers, with the concomitant production of a hydrophilic acyclic hydroxyester with de-icing properties (Fuel Dehydrating Icing Inhibitors - FDII). To this end, a kinetic appraisal of the hydrolysis reactions of representative geminal ethers was undertaken using a convenient surrogate for the fuel-water interface $\left(\mathrm{D}_{2} \mathrm{O} / \mathrm{CD}_{3} \mathrm{CN}\right.$ 1:4). We present here a library of acyclic and five/six-membered cyclic geminal ethers arranged according to their hydroxonium catalytic coefficients for hydrolysis, providing for the first time a framework for the development of FDII. A combination of ${ }^{1} \mathrm{H}$ NMR, labelling and computational studies was used to assess the effects that may govern the observed relative rates of hydrolyses.
\end{abstract}

\section{Introduction}

Our interest in organic dehydrating agents for applications in the aeronautical industry is stimulated by the commercial case for developing a new approach to managing water contamination in jet fuel. The acid-catalysed hydrolysis reactions of cyclic orthoesters present an attractive platform from which to develop Fuel Dehydrating Ice Inhibitors (FDII) [1], since jet fuel is itself mildly acidic [2] and the products of hydrolysis can in principle afford protection against ice formation by residual water [3]. From Brønsted's ground-breaking work on acid catalysis [4], to more recent investigations as models for glycosidic bond cleavage [5], orthoesters have been examined using a range of methods, solvents (i.e., water, methanol, dioxane, and mixtures thereof), and conditions [6,7]. It has been difficult to draw upon this disparate body of data for our purposes, as potential FDII will operate under non-buffered, relatively apolar conditions. Though easily stated, the mechanism for the formation of a charged intermediate [5,7-11] followed by attack of water, cleavage of $\mathrm{RO}-\mathrm{C}$ bonds, and several proton-transfer reactions 
is non-trivial $[6,8,10,12,13]$; and indeed the debate about the factors influencing the overall rate of reaction and the synchronicity of steps has yet to achieve consensus $[11,14,15]$ Factors such as solvent [13], catalyst $\mathrm{p} K_{\mathrm{a}}$ [9], -OR basicity $[6,16,17]$, the kinetic anomeric effect [18], the impact of substituents upon the formation [10,11,19-22] and reactivity of charged intermediates [14] have all attracted scrutiny. A generic 2-alkoxy-2-alkyl-1,3-dioxolane $\mathbf{A}$ is used to illustrate the generally accepted specific acid-catalysed three-stage hydrolysis mechanism of orthoesters (Scheme 1) [23].

$$
\begin{aligned}
& \text { Stage } 1 \underbrace{\mathrm{O}_{\mathrm{O}}^{\mathrm{RO}} \mathrm{X}}_{\mathbf{A}}+\mathrm{HA} \frac{k_{1}\left[\mathrm{H}^{+}\right]}{k_{-1}}[\underbrace{\mathrm{O} \hat{\Theta}^{\mathrm{O}} \mathrm{O}}_{\mathbf{B}}]+\mathrm{A}^{-}+\mathrm{ROH}
\end{aligned}
$$

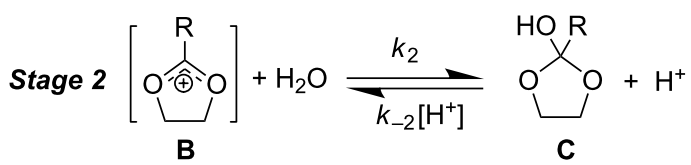

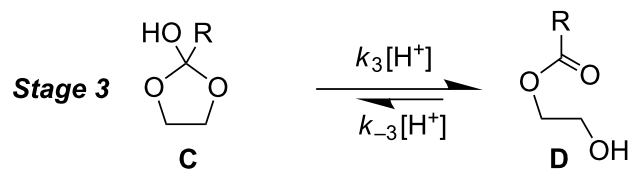

Scheme 1: The three-stage mechanism for the specific acid-catalysed hydrolysis of cyclic orthoester $\mathbf{A}$.

The first stage sees the generation of 1,3-dioxolan-2-ylium cation $\mathbf{B}$ along with alcohol; as water is usually in excess the reverse reaction with $\mathrm{ROH}$ (i.e., $k_{-1}$ ) is considered negligible. It has been established that cyclic orthoesters, and in particular those derived from 1,3-dioxolanes, initially undergo exclusive cleavage of the exocyclic alkoxy group [19]. In reviewing the case of orthoesters, Kresge et al. suggests two mechanistic extremes [19,24]. A concerted catalysed process, wherein the -OR group undergoes protonation as the $\mathrm{C} \cdots \mathrm{O}\left(\mathrm{H}^{+}\right) \mathrm{R}$ bond begins to undergo cleavage. The alternative stepwise process involves the $\mathrm{C}-\mathrm{OR}$ bond spontaneously cleaving at a rate similar to that of $\mathrm{RO}^{-}$protonation by $\mathrm{H}_{3} \mathrm{O}^{+}$. The latter describes a spontaneous uncatalysed hydrolysis. In the case of 1,3-dioxolanes, the concerted mechanism is believed to dominate [25]; however Guthrie [9] asserts that orthoesters are in fact delicately poised between stepwise and concerted processes; depending upon the substituent, both mechanisms are operational for aryl dimethyl orthoformates [21]. Stage 2 sees reaction of $\mathbf{B}$ with $\mathrm{H}_{2} \mathrm{O}$ to afford 2-hydroxy-1,3-dioxolane $\mathbf{C}$ (i.e., $k_{2}$ ) with the overall equilibrium constant $K_{2}=k_{2} / k_{-2}\left[\mathrm{H}^{+}\right]$. Finally, stage 3 sees the acid-catalysed (i.e., $k_{3}\left[\mathrm{H}^{+}\right]$) cleavage of $\mathbf{C}$ to afford hydroxy ester $\mathbf{D}$.

For acyclic geminal ethers stage 1 is invariably rate limiting, i.e., $k_{3}>k_{1}$. For cyclic systems $k_{-3}$ becomes more dominant in the $\mathrm{pH}$ range of about 4-6 [23], however stage 1 remains rate limiting [26]. The overall rate of reaction can therefore be established by measuring the consumption of the geminal ether [27]. We present here kinetic data measured for a range of acyclic orthoformates, orthoacetates, 1,3-dioxolane orthoesters, oxanes, and 1,3-dioxanes (Figure 1), and consider the factors which may modulate the rates of hydrolyses.

\section{Results and Discussion}

The ratio of rates corresponding to the hydrolysis of some sixmembered ketals and orthoesters were reported previously [18]. Employing a similar approach using the same solvent system (i.e., $\mathrm{D}_{2} \mathrm{O} / \mathrm{CD}_{3} \mathrm{CN} 1: 4 \mathrm{v} / \mathrm{v}$ ), quantitative rate data for the hydrolysis reactions of acyclic and cyclic derivatives 1-16 were de-

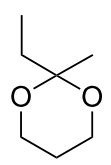

1

$\left(\text { ca. } 4 \times 10^{-3}\right)^{a}$

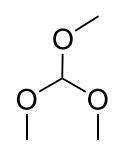

2<smiles>CCOC(OCC)OCC</smiles>

3<smiles>COC1(C)CCCCO1</smiles><smiles>COC1(C)OCCO1</smiles>

5

4<smiles>COC(C)(OC)OC</smiles>

6

$\left(16.9 \pm 0.4 \times 10^{-1}\right)$

$(\text { ca. 3) })^{\mathrm{a}}$

$(6.5 \pm 0.2)$

$(7.0 \pm 0.2)$

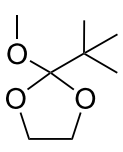

7

$(\text { ca. } 8)^{\mathrm{b}}$

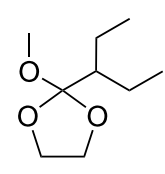

9

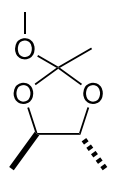

10

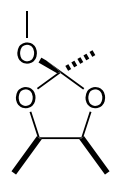

11

(ca. 11)

$(12.1 \pm 0.9)$

$(12.9 \pm 1.0)$

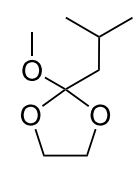

12

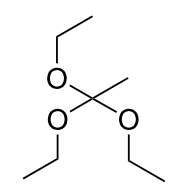

13

$(20.1 \pm 0.9)$

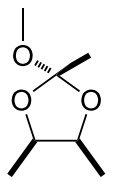

14

$(27.9 \pm 1.7)$<smiles>COC1(OC)CCCCO1</smiles>

15

(ca. 49)
8

$(9.8 \pm 0.2)$
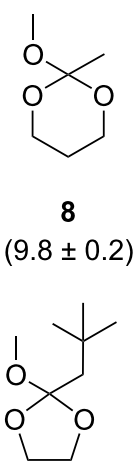

16

$(75.9 \pm 7.1)$

Figure 1: Hydroxonium catalytic coefficients $\left(k_{\mathrm{H}+} \mathrm{M}^{-1} \mathrm{~s}^{-1}\right.$ including standard errors where appropriate) for 1-16 as determined in this study. ${ }^{\text {a,b }}$ Values of $k_{\mathrm{H}+}$ determined via calibration with respect to 8 [18] and 16 [23], respectively (see Experimental section). 
termined, affording a library of potential FDII, organised unambiguously by hydroxonium catalytic coefficient $k_{\mathrm{H}+}$ (Figure 1 , $k_{\mathrm{H}+} \mathrm{M}^{-1} \mathrm{~s}^{-1}$ in parentheses; see Supporting Information File 1 for further details). The observed rate constants $\left(k_{\text {obs }}\right)$ were determined using the rate equation integrated over time, using ${ }^{1} \mathrm{H}$ NMR spectroscopy to evaluate relative concentrations at $25 \pm 0.5^{\circ} \mathrm{C}$. Having already established [1] that specific acid catalysis is more likely to be the dominant mechanism operating in jet fuel/water mixtures, the complications attending the use of buffered systems (and potential $k_{3}$ catalysis by $\mathrm{A}^{-}$) are circumvented by using mineral acid (i.e., $\mathrm{HCl}$, where $\left[\mathrm{H}^{+}\right]$was confirmed via the measurement of $\left[\mathrm{Cl}^{-}\right]$using ion chromatography). The observed rate constant for hydrolysis increases linearly with increasing catalyst concentration, i.e., $k_{\mathrm{obs}}=k_{\mathrm{H}+}$ $\left[\mathrm{H}^{+}\right]$. Nevertheless, we have used the same acid catalyst concentration $\left(\left[\mathrm{H}^{+}\right]=2 \times 10^{-4} \mathrm{M}\right)$ as previous workers [18] except in the case of particularly slow reactions where $\left[\mathrm{H}^{+}\right]$was increased to $5 \times 10^{-4} \mathrm{M}$ to ensure completion within a reasonable time.

\section{Acyclic orthoesters}

Previous workers compared the rates of hydrolysis for cyclic $\mathbf{1}$, 4, 8 and 15 as determined in $\mathrm{D}_{2} \mathrm{O} / \mathrm{CD}_{3} \mathrm{CN}(1: 4 \mathrm{v} / \mathrm{v})$ with acyclic derivatives whose rates were established in water [18]. Further, the literature suggests that acyclic $\mathbf{3}$ and $\mathbf{6}$ hydrolyse at similar rates (i.e., $k_{\mathrm{H}^{+}}=1.4$ and $1.2 \times 10^{4} \mathrm{M}^{-1} \mathrm{~s}^{-1}$, respectively) [4,7] which is surprising given the charge stabilisation expected to accompany the replacement of an $\mathrm{H}$ atom with a methyl group. A comparison of the relative rates of pairs of acyclic orthoesters (i.e., $2+3,2+6$, and $3+\mathbf{1 3}$ ) was performed to address such inconsistencies. An eleven-fold increase in the hydroxonium catalytic coefficient accompanies the replacement of the MeOwith EtO- moieties in orthoformates $\mathbf{2} \rightarrow \mathbf{3}$ (Figure 1). A threefold increase in $k_{\mathrm{H}+}$ accompanies $\mathrm{MeO} \rightarrow$ EtO for orthoacetates $\mathbf{6} \rightarrow \mathbf{1 3}$. As expected, alkyl substituents on the carbonyl carbon atom have a greater accelerating influence on the overall rate of hydrolysis $(\mathrm{H} \rightarrow \mathrm{Me}$ ca. 50-fold) compared to the ethereal substituent ( $\mathrm{Me} \rightarrow$ Et 3-11-fold), with the fastest rate of hydrolysis for acyclic systems considered here being achieved by $13\left(k_{\mathrm{H}^{+}}=20.1 \pm 0.9 \mathrm{M}^{-1} \mathrm{~s}^{-1}\right)$.

\section{The relative reactivity of six-membered cyclic ketals and orthoesters}

The ratio of rates for hydrolysis (as opposed to $k_{\mathrm{H}+}$ ) for $\mathbf{1 , 4 , 8}$ and $\mathbf{1 5}$ have been reported previously [18]. We prepared $\mathbf{8}$ and evaluated $k_{\mathrm{H}+}$ using the same conditions employed by these workers to calibrate values of $k_{\mathrm{H}+}$ for $\mathbf{1}, \mathbf{4}$, and 15 (Figure 1). Acyclic $\mathbf{6}$ was also examined alongside $\mathbf{8}$ to correlate the hydroxonium catalytic coefficients of the hydrolysis reactions of cyclic and acyclic derivatives in this study. It is clear that exo-cyclic orthoester $\mathbf{1 5}$ is the faster reacting geminal ether of the series, hydrolysing at five-times the rate of constitutionally isomeric 8 (Figure 1). The kinetic anomeric effect was invoked previously to rationalise the relative reactivity of $\mathbf{1 5}$ with respect to endo-cyclic 8 [18]. One would anticipate a significant change in rate to accompany the reduction of charge-stabilising oxygen atoms within 8 to afford 4 ; yet $k_{\mathrm{H}+}(\mathbf{8}) / k_{\mathrm{H}+}(4) \approx$ 13:4. The antiperiplanar lone pair hypothesis (ALPH) proposes that the axial anomer of $\mathbf{4}$ constitutes the major conformer in solution [28], perhaps affording some stereoelectronic advantage to an early transition state which appears operative in the case of such acid-catalysed processes [29]. The stereoelectronic advantage [30] of an endo-cyclic oxygen atom in 4 may mitigate the loss of an electrostatically stabilising oxygen atom from the system. The hydroxonium catalytic coefficient for the hydrolysis of $\mathbf{1}$ is $\approx 650$ times slower than observed for the constitutional isomer 4 . Acid-catalysed cleavage of the former affords a leaving group covalently tethered to a cation which renders the overall rate apparently slow, perhaps through a favoured re-cyclisation. It is noteworthy that the hydroxonium catalytic coefficient for the hydrolysis - albeit measured in water - of a similar yet acyclic ketal (i.e., 2,2-diethoxypropane) is several orders of magnitude greater than $\mathbf{1}$ [18].

\section{Relative reactivity of cyclic orthoesters; five versus six-membered rings}

As $k_{1} \approx k_{\text {obs }}$ in the $\mathrm{pH}$ range examined here (Scheme 1), factors associated with the relief of cyclic strain cannot be used to account for the difference observed for five-membered 5 and six-membered 8 (i.e., $k_{\mathrm{H}^{+}}=6.5$ and $9.8 \mathrm{M}^{-1} \mathrm{~s}^{-1}$ ). Further, the hydroxonium catalytic coefficient for the hydrolysis of $\mathbf{5}$ and acyclic analogue 6 are within experimental error of each other (i.e., $k_{\mathrm{H}+}=6.5 \pm 0.2$ and $7.0 \pm 0.2 \mathrm{M}^{-1} \mathrm{~s}^{-1}$, respectively). It was noted previously that the relative rates of hydrolysis for sixmembered 15 and 8 could be explained with the kinetic anomeric effect. Consistent with this, the X-ray crystal structure of an analogous yet conformationally constrained bicyclic orthoester possesses an unusually elongated axial $\mathrm{C}-\mathrm{O}$ bond (Figure 2a), which undergoes preferential cleavage with Lewis acids [31]. The Cambridge Structural Database (2015) [32] contains a single example of a five-membered 1,3-dioxolane orthoester [33]. Here, the ring adopts a distorted half-chair $\left(C_{2}\right)$ arrangement with a dihedral angle $\theta[\mathrm{O}-\mathrm{C}(4)-\mathrm{C}(5)-\mathrm{O}]=32^{\circ}$ [Figure $2 \mathrm{a}-\mathrm{ZICMED}$ viewed $\mathrm{C}(4) \rightarrow \mathrm{C}(5)$ ]. This, along with a rate of hydrolysis similar to an acyclic system suggests that a kinetic anomeric effect does not extend to 1,3-dioxolane orthoesters.

\section{The reactivity of $\mathrm{C}(4 / 5)$ substituted 1,3-dioxolanes}

Substitution of the 1,3-dioxolane ring at $\mathrm{C}(4 / 5)$ introduces asymmetry with the attendant challenges of isomer separation 


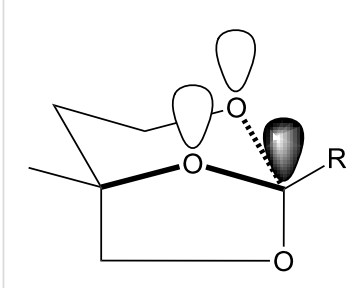

a

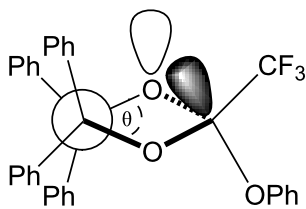

b
Figure 2: Stereoelectronic contributions to hydrolysis; (a) conformationally constrained 1,3-dioxane orthoester; (b) Newman projection of five-membered ZICMED viewed $\mathrm{C}(4) \rightarrow \mathrm{C}(5)$.

and identification. Here, the unambiguous assignment of the crude mix of 10, 11 and 14 via ${ }^{1} \mathrm{H}$ NMR (500 MHz) and 1D-NOESY facilitated kinetic analyses without recourse to separation. The $\mathrm{C}_{2}$ symmetry of $\mathbf{1 4}$ renders the $\mathrm{C}(4 / 5)-\mathrm{CH}_{3}$ and $\mathrm{C}(4 / 5)-H$ nuclei equivalent; the methyl $\mathrm{C}(4 / 5)-\mathrm{CH}_{3}$ $\left[\delta_{\mathrm{Me}}=1.22 / 1.29 \mathrm{ppm}(\mathrm{d}, 3 \mathrm{H}, J=6.0 \mathrm{~Hz})\right]$, and methine $\mathrm{C}(4 / 5)-H\left[\delta_{\mathrm{H}}=3.73 / 3.83 \mathrm{ppm}(\mathrm{m}, 1 \mathrm{H})\right]$ nuclei of $\mathbf{1 0}$ were assigned. Irradiation of the ${ }^{1} \mathrm{H}$ NMR resonance associated with the $\mathrm{C}(2)-\mathrm{CH}_{3}$ nuclei (1.46 ppm) of $\mathbf{1 0}$ afforded strong nOes of the multiplet at $3.73 \mathrm{ppm}$, and the singlet at $3.24 \mathrm{ppm}$, consistent with proximal syn $\mathrm{C}(4 / 5)-\mathrm{H}$, and the geminal $\mathrm{C}(2)-\mathrm{OCH}_{3}$ nuclei, respectively (Figure 3 ). The ${ }^{1} \mathrm{H}$ NMR spectra of $\mathbf{1 1}$ and $\mathbf{1 4}$ were assigned in a similar fashion.

We attribute the two-fold rate increase of 10-11 $\left(k_{\mathrm{H}+} \approx\right.$ $\left.12 \mathrm{M}^{-1} \mathrm{~s}^{-1}\right)$ with respect to $5\left(k_{\mathrm{H}+}=6.5 \mathrm{M}^{-1} \mathrm{~s}^{-1}\right)$ to be steric in origin. The additional two-fold rate acceleration of $\mathbf{1 4}\left(k_{\mathrm{H}^{+}}=\right.$ $27.9 \mathrm{M}^{-1} \mathrm{~s}^{-1}$ ) with respect to $\mathbf{1 0 - 1 1}$ is ascribed to the relief of transannular compression involving the $\mathrm{C}(4 / 5)-M e$ and $M e-\mathrm{C}(2)$ groups, which nOe studies suggest are near to each other in space (see structure 14, Figure 3).

\section{The reactivity of $\mathrm{C}(2)$ substituted}

\section{1,3-dioxolanes}

McClelland et al. [23] has determined $k_{\mathrm{H}^{+}}$for 5, 7, 9, 12 and 16 in a water/phosphate buffer system at $\mathrm{pH} 6-7$; we prepared 5 and $\mathbf{1 6}$ to calibrate their data with the conditions employed here (i.e., $\mathrm{D}_{2} \mathrm{O} / \mathrm{CD}_{3} \mathrm{CN} / \mathrm{HCl}$ ), whilst assuming that the relative magnitudes of the hydroxonium catalytic coefficients remain consis- tent throughout (Table 2, Experimental section). The rates of hydrolysis for $\mathbf{5}$ and $\mathbf{7}$ are essentially the same, indicating that a tert-butyl group at $\mathrm{C} \alpha$ exerts little or no transannular steric demand which might manifest itself in the rate determining step. In the case of $\mathrm{C} \beta$ substituted derivatives, a gradual increase in the hydroxonium catalytic coefficient is observed with respect to $\mathbf{5}$, with a dramatic acceleration noted for the case of $\mathbf{1 6}$ (i.e., $k_{\mathrm{H}^{+}} \mathbf{5}=6.5 ; \mathbf{9} \approx 11 ; \mathbf{1 2} \approx 14 ; \mathbf{1 6}=75.9 \mathrm{M}^{-1} \mathrm{~s}^{-1}$; Figure 1). Inspection of Newman projections (Figure 4) of 9 and 12 reveal incremental 1,3-transannular steric demand associated with $M e-\mathrm{C} \beta$ and $\mathrm{C}(4 / 5)-H$ atoms; consistent with the gradual increase of $k_{\mathrm{H}+}$. In the case of neopentyl 16 however, two $M e-\mathrm{C} \beta$ groups are oriented toward transannular $\mathrm{C}(4 / 5)-H$ atoms at all times, suggesting a means by which this substituent affects a dramatic $(>400 \%)$ rate increase for this substrate - this is examined further.

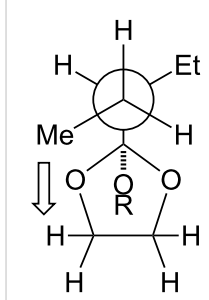

9

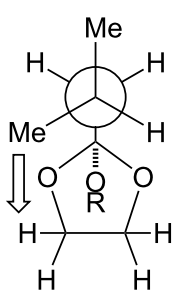

12

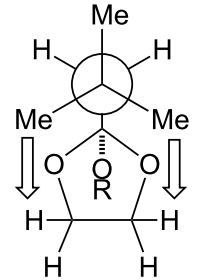

16
Figure 4: Newman projections of 9,12 and 16 (viewed along $C \beta \rightarrow C \alpha$ ).

To understand the significant increase in the hydroxonium catalytic coefficient with varying $\mathrm{C}(2)$ substituent, computational conformational analyses of $\mathbf{5}$ and $\mathbf{1 6}$ were performed using Density Functional Theory to optimise the resultant structures (see Experimental section). The half-chair $\left(C_{2}\right)$ arrangement was found to be the only stable conformer for the 1,3-dioxolane ring with all other conformers being rotamers about the $\mathrm{C}(2)-\mathrm{CH}_{2} \mathrm{R}$ and $\mathrm{C}(2)-\mathrm{OMe}$ bonds [where $\mathrm{R}=\mathrm{H}(5)$ or $t$ - $\mathrm{Bu}$ (16)]. The orientation of the $\mathrm{C}(2) \mathrm{O}-\mathrm{Me}$ group is ignored from this point as it does not substantially affect the relative energies of the $\mathrm{C}(2)-\mathrm{CH}_{2} \mathrm{R}$ rotamers. The potential energy surface for $\mathbf{1 6}$ is dominated by the syn arrangement of $\mathrm{R}$ with respect to the

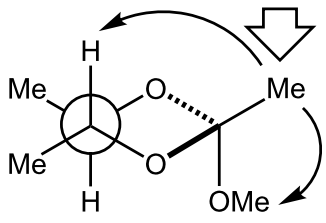

10

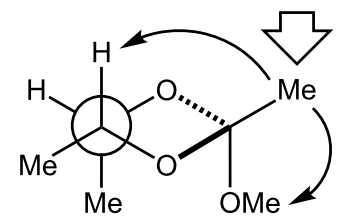

11

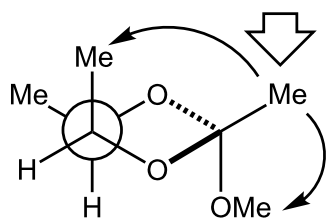

14

Figure 3: The assignment of $\mathbf{1 0 - 1 1}$ and 14 via nOe [viewed $C(4) \rightarrow C(5)$ ] 


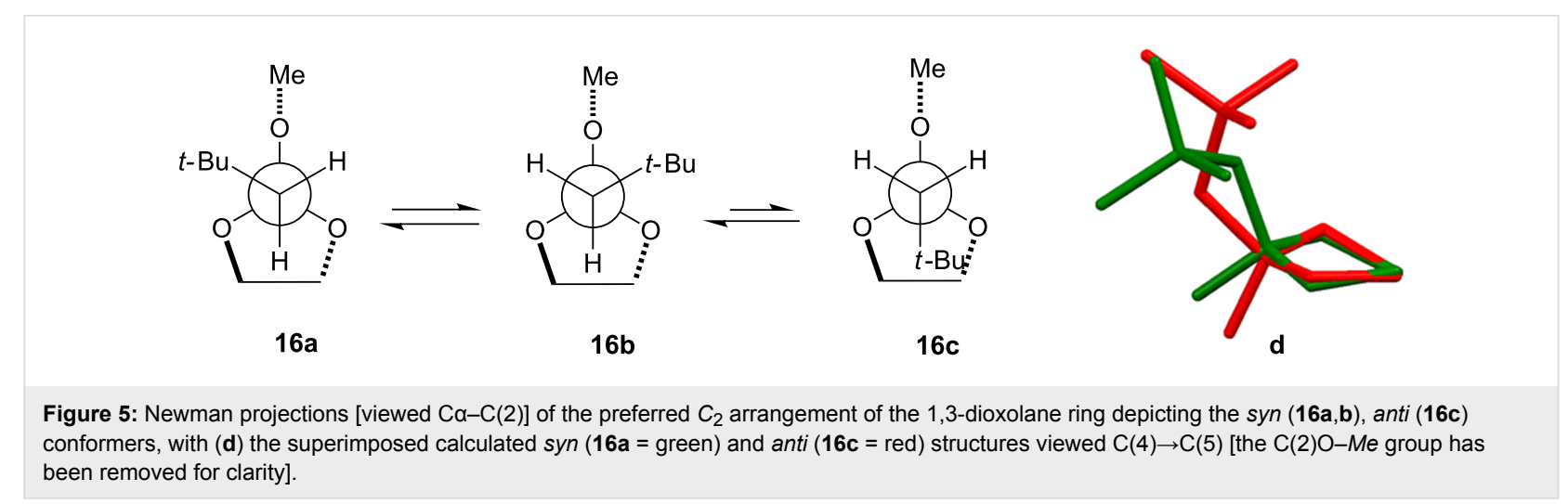

OMe group (16a and 16b in Figure 5; $\Delta \Delta H=0$ and $0.8 \mathrm{~kJ} / \mathrm{mol}$, respectively); the rotamer which orients the $\mathrm{R}$ group anti with respect to the OMe (16c in Figure 5; $\Delta \Delta H=6 \mathrm{~kJ} / \mathrm{mol}$ ) leads to a pseudo-axial orientation of the OMe group through flattening of the 1,3-dioxolane ring (Figure 5d); presumably this relieves steric pressure between the $t$-Bu and $\mathrm{C}(3 / 5)-H$ atoms at a cost of approximately $5.7 \mathrm{~kJ} / \mathrm{mol}$ higher enthalpy. No such flattened conformer exists for $\mathbf{5}$.

The calculations are consistent with the model presented earlier in Figure 4. The increasing steric demand of substituent $\mathrm{R}$ [i.e., $\mathrm{R}=\mathrm{H}(\mathbf{5}) ; \rightarrow \mathrm{Et}(\mathbf{9}) ; \rightarrow \mathrm{iPr}(\mathbf{1 2}) \rightarrow t$-Bu (16)] leads to transannular clashing with axial $\mathrm{C}(3) /(4)-H$ atoms and subsequent flattening of the 1,3-dioxolane ring. For $\mathbf{1 6}$ this affords an energetically accessible conformer $\mathbf{1 6 c}$ which resembles the planar geometry anticipated for the transition state (Scheme 1), and should therefore be entropically favoured following the principle of least molecular motion. To confirm whether there was any enthalpic barrier to elimination of the protonated methoxy group, geometric scans for potential transition-states were made using Density Functional Theory calculations, by incrementally increasing and fixing the $\mathrm{C}(2)-\mathrm{OMe}$ bond length for rotamers 16a-c after protonation, and allowing all other geometry elements to optimise. In all cases, the five-membered ring moved towards the final planar oxonium ion, but no enthalpic barrier was found for the $\mathrm{C}(2)-\mathrm{OMe}$ bond cleavage. This supports entropic control of this elimination reaction, and it is therefore not surprising that the more planar ring for the anti rotamer $\mathbf{1 6 c}$ would lead to a more rapid elimination of methanol after protonation, consistent with an earlier transition state [29]. Compound 5, which does not have such an accessible flattened ring conformation cannot access this lower entropy trajectory and hence reacts more slowly.

\section{Exclusion of $\mathrm{O}(1 / 3)-\mathrm{C}(5 / 4)$ cleavage}

It has been noted that annular strain in trans-2,5-dimethyltetrahydrofurans invokes sufficient charge separation to switch the mechanism of ring cleavage from $S_{\mathrm{N}} 2 \rightarrow S_{\mathrm{N}} 1$ [34]. We therefore sought to exclude the possibility of mechanistic partitioning via some strain-induced $\mathrm{O}(1 / 3)-\mathrm{C}(5 / 4)$ cleavage pathway for the systems under study here. Though the products of hydrolytic attack at $\mathrm{C}(2)$ or $\mathrm{C}(4 / 5)$ are constitutionally indistinguishable, the participation of a $\mathrm{C}(4 / 5)$ pathway brought about through intramolecular strain may be detected using $\mathrm{H}_{2}{ }^{18} \mathrm{O}$ labelling (Scheme 2). The $\mathrm{C}(2)$ attack of cation $\mathbf{B}$ by $\mathrm{H}_{2}{ }^{18} \mathrm{O}$ will afford $\mathbf{D}$ with ${ }^{18} \mathrm{O}$ incorporated at the carbonyl carbon atom alone; acid-catalysed re-closure eliminates the heavy isotope to afford once again, B [35]. Alternatively, strain-induced charge separation with subsequent $\mathrm{H}_{2}{ }^{18} \mathrm{O}$ attack at $\mathrm{C}(4 / 5)$ affords after ring cleavage hydroxy ester $\mathbf{D}$ with ${ }^{18} \mathrm{O}$ incorporated at the $\mathrm{OH}$ function alone; subsequent acid-catalysed re-closure affords $\mathbf{B}$ $\left[{ }^{18} \mathrm{O}\right]$ as isotopically distinct mesomers. Further attack of $\mathbf{B}$ $\left[{ }^{18} \mathrm{O}\right]$ by $\mathrm{H}_{2}{ }^{18} \mathrm{O}$ affords $\mathbf{D}\left[2 \times{ }^{18} \mathrm{O}\right]$. In short, an ambident cation $\mathbf{B}$ exposed to repetitive $\mathrm{C}(4 / 5) \mathrm{H}_{2}{ }^{18} \mathrm{O}$ attack will ultimately afford a product incorporating ${ }^{18} \mathrm{O}$ at all oxygen containing functions, i.e., $\mathbf{D}\left[3 \times{ }^{18} \mathrm{O}\right]$.

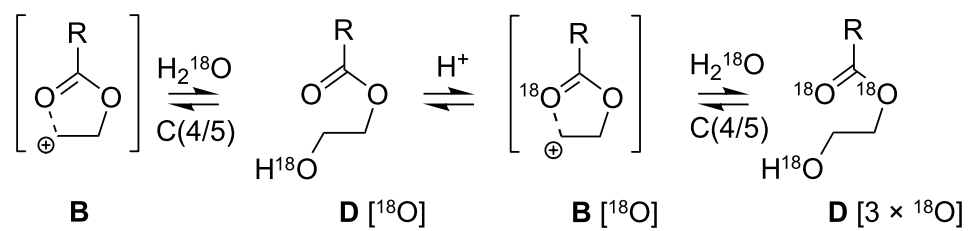


We examined $\mathbf{5}$ alongside $\mathbf{1 6}$ as the former, which hydrolyses at $10 \%$ the rate of the latter, is not assumed to experience any significant degree of strain. The 1,3-dioxolan-2-ylium salts derived from $5\left(\mathbf{5}^{*}\right.$, i.e., $\left.\mathbf{B} \mathrm{R}=\mathrm{Me}\right)$ and $\mathbf{1 6}(\mathbf{1 6 *}$, i.e., $\mathbf{B}$ where $\mathrm{R}=n$-Pent) were prepared via an unambiguous route [36-38] and quenched using $\mathrm{H}_{2}{ }^{16} \mathrm{O}$ or $\mathrm{H}_{2}{ }^{18} \mathrm{O}$ and analysed via $\mathrm{MS}(\mathrm{CI})$. The $[\mathrm{M}+\mathrm{H}]^{+}$and $[(\mathrm{M}+2)+\mathrm{H}]^{+}$ions derived from the reaction of $5^{*}$ and $16^{*}$ with $\mathrm{H}_{2}{ }^{16 / 18} \mathrm{O}$ alone were evident, indicating the incorporation of a single ${ }^{18} \mathrm{O}$ atom. To establish the site of isotope incorporation, crude mixtures were examined via ${ }^{13} \mathrm{C}$ NMR which identified in both cases a characteristic upfield shift $\left(\Delta \delta_{C}=0.04 \mathrm{ppm}\right)$ of the resonance attributed to the carbonyl carbon atom $[39,40]$, consistent with $C(2)$ attack alone. We confirm therefore that the dramatic rate acceleration noted for $\mathbf{1 6}$ is not consistent with a change in mechanism [41].

\section{Conclusion}

A range of promising FDII candidates based upon acyclic and cyclic geminal ethers, unambiguously organised according to their catalytic coefficients $k_{\mathrm{H}+}$ in $\mathrm{CD}_{3} \mathrm{CN} / \mathrm{D}_{2} \mathrm{O} 4: 1$ has been presented (Figure 1). As anticipated, orthoacetates possessing ethoxy substituents are the most rapidly hydrolysed acyclic systems. Both entropic and steric effects are believed to account for the relatively fast rates of hydrolysis of cyclic orthoesters with respect to ketals. Rate increases within five-membered endo-cyclic orthoesters accompany increasingly bulky $\mathrm{C}(2)$ alkyl substitution. Dramatic increases in the hydroxonium catalytic coefficients for hydrolysis are observed for $\mathrm{C} \beta$ branching at $\mathrm{C}(2)$, which can lead to conformational distortion of the fivemembered ring which lowers the activation barrier to elimination of the OMe group and formation of the intermediate oxonium ion. The dual performance of cyclic geminal ethers as FDII for jet fuels will be reported shortly.

\section{Experimental}

All preparative operations were performed at the synthetic laboratories of the School of Chemistry, University of Bristol. NMR spectra were recorded on a JEOL ECP Eclipse 300 spectrometer at $300 \mathrm{MHz}\left({ }^{1} \mathrm{H}\right)$, a JEOL ECP Eclipse 400 spectrometer at $400 \mathrm{MHz}\left({ }^{1} \mathrm{H}\right)$ and $100 \mathrm{MHz}\left({ }^{13} \mathrm{C}\right)$ or a Varian VNMRS 500 spectrometer at $500 \mathrm{MHz}\left({ }^{1} \mathrm{H}\right)$ in deuterated solvents (University of Bristol). Mass spectra (HRMS) were obtained on a Micromass AutoSpec MS in CI mode using $\mathrm{CH}_{4}$ as the collision gas. HRMS and elemental analysis were performed by the respective services at the School of Chemistry, University of Bristol.

Orthoester hydrolysis kinetics. The reacting pair of $\mathbf{2}$ and $\mathbf{6}$ has been used here to illustrate a typical procedure. Adjustments to the acid catalyst concentration were made on an iterative basis in order to ensure the kinetic runs were complete within reasonable time-scales. Freshly distilled $2(33 \mu \mathrm{L}$, $0.3 \mathrm{mmol})$ and $6(38 \mu \mathrm{L}, 0.3 \mathrm{mmol})$ were added to anhydrous $\mathrm{CD}_{3} \mathrm{CN}(1200 \mu \mathrm{L})$, and the resulting solution was divided equally into three dry $5 \mathrm{~mm}$ NMR tubes. ${ }^{1} \mathrm{H}$ NMR $(300 \mathrm{MHz})$ spectroscopy was used to confirm the resulting 1:1 ratio of 2 and $\mathbf{6}$ in each sample. To minimise contamination by $\mathrm{H}_{2} \mathrm{O}$, acid solutions were prepared by the successive dilution of $\mathrm{HCl}$ $(35 \% \mathrm{v} / \mathrm{v})$ with $\mathrm{D}_{2} \mathrm{O}$. In this manner, a solution of $\left[\mathrm{H}^{+}\right]=$ $4.78 \times 10^{-4} \mathrm{M}$ was prepared; $\left[\mathrm{H}^{+}\right]$was confirmed via the measurement of $\left[\mathrm{Cl}^{-}\right]$using ion chromatography. The hydrolysis reaction was initiated by the addition of $\mathrm{HCl}$ in $\mathrm{D}_{2} \mathrm{O}(100 \mu \mathrm{L}$, $\left.4.78 \times 10^{-8} \mathrm{~mol}\right)$ to the NMR tube. Data was acquired every $625 \mathrm{~s}$ until the faster of the pair was consumed. NMR kinetic measurements were temperature-controlled at $25 \pm 0.5^{\circ} \mathrm{C}$ using the variable temperature control unit of the spectrometer (instrument temperature calibration performed with an internal NMR methanol thermometer). A semi-logarithmic plot of the integral of the resonances associated with $2\left(\delta_{\mathrm{H}}=4.93 \mathrm{ppm}\right)$, and $\mathbf{6}$ $\left(\delta_{\mathrm{H}}=1.35 \mathrm{ppm}\right)$ against time (s) affords two straight lines with gradient $=k_{\mathrm{obs}}$, which when divided by $\left[\mathrm{H}^{+}\right]$, provides the catalytic coefficient $k_{\mathrm{H}+}$. The process was repeated a further two times using the pre-prepared samples. The value of $k_{\mathrm{H}+}$ remains constant throughout the range $\left[\mathrm{H}^{+}\right] \approx 5 \rightarrow 10 \times 10^{-5} \mathrm{M}$, thereby confirming that it is only necessary to measure $k_{\mathrm{obs}}$ for a given value of $\left[\mathrm{H}^{+}\right]$in order to determine $k_{\mathrm{H}^{+}}$(Table 1$)$.

\begin{tabular}{|c|c|c|c|c|}
\hline \multirow{2}{*}[\mathrm{HCl}]{$\times 10^{-5} \mathrm{M}$} & \multicolumn{2}{|c|}{$k_{\mathrm{obs}} \times 10^{-6} \mathrm{~s}^{-1}$} & \multicolumn{2}{|c|}{$k_{\mathrm{H}+} \mathrm{M}^{-1} \mathrm{~s}^{-1}$} \\
\hline & 2 & 6 & 2 & 6 \\
\hline 9.56 & 14.6 & 678 & 0.150 & 7.09 \\
\hline 6.38 & 9.4 & 447 & 0.147 & 7.01 \\
\hline 5.31 & 7.7 & 363 & 0.145 & 6.84 \\
\hline
\end{tabular}

\section{Calibration of rate data}

Table 2: The ratio of the rates of hydrolysis for $1,4,8$ and 15.

\begin{tabular}{ccc} 
& Rate ratios $^{\mathrm{a}}$ & $k_{\mathrm{H}+}\left(\mathrm{M}^{-1} \mathrm{~s}^{-1}\right)^{\mathrm{b}}$ \\
\hline $\mathbf{1}$ & 1 & $\approx 4 \times 10^{-3}$ \\
$\mathbf{4}$ & 649 & $\approx 3$ \\
$\mathbf{1 5}$ & 2270 & $9.8 \pm 0.2$ \\
\hline
\end{tabular}

aDetermined in $\mathrm{D}_{2} \mathrm{O} / \mathrm{CD}_{3} \mathrm{CN}(1: 4 \mathrm{v} / \mathrm{v})$ as reported by Deslongchamps et al. [18], where the relative reaction rates were determined across a range of $\left[\mathrm{H}^{+}\right]$(errors not reported in original work). b Values of $\mathrm{k}_{\mathrm{H}+}$ estimated through calibration with the experimentally determined value of 8 established by this work. 
Table 3: Calibrating ratios of $k_{1}{ }^{\mathrm{H}}$ for $5,7,9,12$ and 16 with respect to experimentally determined values of 5 and 16 from this study.

\begin{tabular}{ccccc} 
& $k_{1}{ }^{\mathrm{H}}$ ratio $^{\mathrm{a}}$ & $k_{\mathrm{H}+}\left(\mathrm{M}^{-1} \mathrm{~s}^{-1}\right)^{\mathrm{b}}$ & $k_{\mathrm{H}+}\left(\mathrm{M}^{-1} \mathrm{~s}^{-1}\right)^{\mathrm{c}}$ & - \\
\hline $\mathbf{5}$ & 1 & $6.5 \pm 0.2$ & - & $6.5 \pm 0.2$ \\
$\mathbf{6}$ & - & - & $\approx 8$ & $7.0 \pm 0.2$ \\
7 & 2.0 & $\approx 13$ & $\approx 11$ & - \\
9 & 2.6 & $\approx 17$ & $\approx 14$ & - \\
12 & 3.4 & $\approx 22$ & $\approx 76$ & $75.9 \pm 7.1$ \\
\hline
\end{tabular}

aThe ratio of $k_{1}{ }^{H}$ (equivalent to $k_{\mathrm{H}+}$ in this work) determined in water/phosphate buffer are considered here as we believe that [23] contains typographical errors in the reported exponential factors. ${ }^{b}$ Calibration of $k_{1}{ }^{H}$ ratios with respect to the experimentally determined value of $5^{d}$ then $16^{c}(\times 76 / 123)$. For consistency, $\mathbf{6}$ and $\mathbf{5}$ were paired for kinetic runs.

Preparations. The acyclic orthoesters 2, 3, 6 and $\mathbf{1 3}$ are commercially available, whereas the cyclic derivatives $\mathbf{5}$ [23,42], 8 [43,44], 10 [43], and 16 [23,36,45] were prepared via known procedures. Though mixtures of 10, 11 and 14 have been prepared previously [46,47], $\mathbf{1 1}$ and $\mathbf{1 4}$ have not been characterised. Thus, freshly distilled $\mathbf{6}(9.3 \mathrm{~mL}, 73 \mathrm{mmol})$ was added with stirring to a pre-cooled $\left(0^{\circ} \mathrm{C}\right)$ solution of 2,3-butanediol (6.6 g, $73 \mathrm{mmol}$ ), and $\mathrm{H}_{2} \mathrm{SO}_{4}(100 \mu \mathrm{L}, 2.4 \mathrm{mmol})$ in diethyl ether $(30 \mathrm{~mL})$ under nitrogen. The reaction was quenched after 24 hours by the addition of imidazole $(0.4 \mathrm{~g}, 6 \mathrm{mmol})$, and the resulting cloudy solution was washed with saturated aqueous $\mathrm{NaHCO}_{3}(200 \mathrm{~mL})$, filtered and extracted with diethyl ether $(3 \times 50 \mathrm{~mL})$. The combined organic extracts were dried $\left(\mathrm{MgSO}_{4}\right)$, and concentrated in vacuo to afford a clear colourless liquid characterised (via 1D NOESY ${ }^{1} \mathrm{H}$ NMR spectroscopy) as a mixture of $10(30 \%), \mathbf{1 1}(20 \%)$ and $\mathbf{1 4}(50 \%)(6.9 \mathrm{~g}$, $65 \%$ ). Repeated distillations $\left(37^{\circ} \mathrm{C}, 10 \mathrm{mmHg}\right.$ ) failed to afford separation, and column chromatography $\left(\mathrm{SiO}_{2}\right.$, petroleum ether/ ethyl acetate/triethylamine 15:4:1) resulted in the hydrolysis of products. $\delta_{\mathrm{H}}(\mathbf{1 0})[43]\left(500 \mathrm{MHz}, \mathrm{CDCl}_{3}\right) 1.25(\mathrm{~d}, J=6.0 \mathrm{~Hz}$, $3 \mathrm{H}), 1.30(\mathrm{~d}, J=6.0 \mathrm{~Hz}, 3 \mathrm{H}), 1.53(\mathrm{~s}, 3 \mathrm{H}), 3.29(\mathrm{~s}, 3 \mathrm{H}), 3.72$ $(\mathrm{m}, 1 \mathrm{H}), 3.84(\mathrm{~m}, 1 \mathrm{H}) ; \delta_{\mathrm{H}}(\mathbf{1 1})\left(500 \mathrm{MHz}, \mathrm{CDCl}_{3}\right) 1.22(\mathrm{~m}$, $6 \mathrm{H}), 1.50(\mathrm{~s}, 3 \mathrm{H}), 3.30(\mathrm{~s}, 3 \mathrm{H}), 4.29(\mathrm{~m}, 2 \mathrm{H}) ; \delta_{\mathrm{H}}(\mathbf{1 4})$ $\left(500 \mathrm{MHz}, \mathrm{CDCl}_{3}\right) 1.15(\mathrm{~m}, 6 \mathrm{H}), 1.56(\mathrm{~s}, 3 \mathrm{H}), 3.28(\mathrm{~s}, 3 \mathrm{H})$, $4.41(\mathrm{~m}, 2 \mathrm{H}) . \delta_{\mathrm{C}}(\mathbf{1 0}, \mathbf{1 1}, 14)\left(100 \mathrm{MHz}, \mathrm{CDCl}_{3}\right) 15.3,15.5$, 17.0, $\left.17.4\left[\mathrm{C}(4 / 5)-\mathrm{CH}_{3}\right)\right], 22.5,23.3,23.6\left[\mathrm{C}(2)-\mathrm{CH}_{3}\right], 49.3 *$, $50.5\left(-\mathrm{OCH}_{3}\right), 73.9,74.6,79.1,79.6[C(4 / 5)], 120.0,121.0$ $[C(2)]$. *Signal splitting of $\Delta \delta=0.09 \mathrm{ppm}$ observed. HRMS-ESI calculated for $[\mathrm{M}+\mathrm{Na}]^{+} 169.0835$, found: 169.0836 .

The distribution of products resulting from the exchange reaction of 6 with $d l$ - and meso-2,3-butanediol warrants brief comment; reaction of the former affords 10 [43], whereas the latter gives $\mathrm{C}(2)$ epimers 11 and 14. Both GC-MS and ${ }^{1} \mathrm{H}$ NMR analyses (see Supporting Information File 1) of the crude generated by treatment of 6 with a 1:1 mixture of $d l / m e s o-2,3$-butane- diol indicates 10/11/14 are formed in the ratio 3:2:5, respectively ( $63 \%$ conversion). Yet treatment of 6 with commercially available 2,3-butanediol (77:23 meso- and $d l$-, respectively by ${ }^{1} \mathrm{H}$ NMR [48]) also affords the same product ratio with $65 \%$ conversion. Performing the procedure at -10 and $+20{ }^{\circ} \mathrm{C}$ does not change the product distribution; we conclude then, that the exchange reaction proceeds via equilibrium control.

Computational techniques. X-ray crystal structures were located in the 2014 release of the Cambridge Structural Database (CSD v 5.35, which contains 658, 007 entries) using the Conquest software (v 1.16) and visualised using the Mercury software package (v 3.1). Conformational searching was conducted with Macromodel software, using a MonteCarlo search method and the MMFF force field. Final molecular geometries were optimised using the Gaussian09 [49] with density functional level of theory, using the hybrid functional B3LYP/6$31 \mathrm{G}^{*}$ to optimise structures [50-52], with convergence criteria for maximum and RMS force (0.000450 and 0.000300 in atomic units per Bohr and per radian respectively) and for atomic displacements (0.001800 and 0.001200 Angstroms, respectively).

\section{Supporting Information}

Supporting Information features copies of an indicative ${ }^{1} \mathrm{H}$ NMR stacked plot (2/6), 1D NOESY spectra (10/11/14), $\operatorname{MS}(\mathrm{CI})$ spectra $\left(\mathbf{5}^{*} / \mathbf{1 6}^{*}\right)$, experimentally determined values of $k_{\mathrm{H}+}$ for the reacting mixtures of geminal ethers: [6+2], $[3+2],[6+13],[6+5],[6+8],[6+10+11+14]$, $[\mathbf{6}+\mathbf{1 6}]$, and Cartesian coordinates of conformers 16c.

\section{Supporting Information File 1}

Analytical data.

[http://www.beilstein-journals.org/bjoc/content/ supplementary/1860-5397-12-143-S1.pdf] 


\section{Acknowledgements}

Funded by the UK Engineering and Physical Sciences Research Council (EPSRC Grant Number EP/H501525/1) and Airbus Operations Ltd through the EPSRC Industrial CASE award.

\section{References}

1. Repetto, S. L.; Costello, J. F.; De Lacy Costello, B.; Ratcliffe, N. M.; Lam, J. K.-W. SAE Int. J. Fuels Lubr. 2013, 6, 553-563. doi:10.4271/2013-01-2169

2. C.R.C. Handbook of Aviation Fuel Properties (CRC Report No. 635); 2004.

3. Repetto, S. L.; Patel, R.; Johnson, T.; Costello, J. F.; Lam, J. K.-W.; Chuck, C. J. Energy Fuels submitted.

4. Brönsted, J. N.; Wynne-Jones, W. F. K. Trans. Faraday Soc. 1929, 25, 59-76. doi:10.1039/TF9292500059

5. Buckley, N.; Oppenheimer, N. J. J. Org. Chem. 1996, 61, 8048-8062. doi:10.1021/jo960748t

6. Cordes, E. H.; Bull, H. G. Chem. Rev. 1974, 74, 581-603. doi:10.1021/cr60291a004

7. Chiang, Y.; Kresge, A. J.; Lahti, M. O.; Weeks, D. P. J. Am. Chem. Soc. 1983, 105, 6852-6855. doi:10.1021/ja00361a017

8. Fife, T. H. Acc. Chem. Res. 1972, 5, 264-272. doi:10.1021/ar50056a002

9. Guthrie, J. P. J. Am. Chem. Soc. 1980, 102, 5286-5293. doi:10.1021/ja00536a028

10. Jensen, J. L.; Wuhrman, W. B. J. Org. Chem. 1983, 48, 4686-4691. doi:10.1021/jo00172a045

11. Belarmino, A. T. N.; Froehner, S.; Zanette, D.; Farah, J. P. S.; Bunton, C. A.; Romsted, L. S. J. Org. Chem. 2003, 68, 706-717. doi:10.1021/j00202987

12. Fife, T. H. J. Am. Chem. Soc. 1967, 89, 3228-3231. doi:10.1021/ja00989a024

13. Young, P. R.; Bogseth, R. C.; Rietz, E. G. J. Am. Chem. Soc. 1980, 102, 6268-6271. doi:10.1021/ja00540a015

14. Richard, J. P.; Williams, K. B.; Amyes, T. L. J. Am. Chem. Soc. 1999, 121, 8403-8404. doi:10.1021/ja9915293

15. Hartwell, E.; Hodgson, D. R. W.; Kirby, A. J. J. Am. Chem. Soc. 2000, 122, 9326-9327. doi:10.1021/ja002335m

16. Kankaanperä, A. Acta Chem. Scand. 1969, 23, 1723-1727. doi:10.3891/acta.chem.scand.23-1723

17. Lahti, M.; Kauppi, K. Acta Chem. Scand. 1986, 40A, 533-537. doi:10.3891/acta.chem.scand.40a-0533

18. Deslongchamps, P.; Dory, Y. L.; Li, S. Tetrahedron 2000, 56, 3533-3537. doi:10.1016/S0040-4020(00)00270-2

19. Burt, R. A.; Chambers, C. A.; Chiang, Y.; Hillock, C. S.; Kresge, A. J.; Larsen, J. W. J. Org. Chem. 1984, 49, 2622-2624. doi:10.1021/jo00188a022

20. Wiberg, K. B.; Martin, E. J.; Squires, R. R. J. Org. Chem. 1985, 50, 4717-4720. doi:10.1021/jo00224a011

21. Lahti, M. Acta Chem. Scand. 1987, 41a, 93-97. doi:10.3891/acta.chem.scand.41a-0093

22. Fife, T. H.; Bembi, R.; Natarajan, R. J. Am. Chem. Soc. 1996, 118, 12956-12963. doi:10.1021/ja953362t

23. Santry, L. J.; Azer, S.; McClelland, R. A. J. Am. Chem. Soc. 1988, 110, 2909-2914. doi:10.1021/ja00217a036

24. Chiang, Y.; Kresge, A. J.; Salomaa, P.; Young, C. I. J. Am. Chem. Soc. 1974, 96, 4494-4499. doi:10.1021/ja00821a024

25. Bergstrom, R. G.; Cashen, M. J.; Chiang, Y.; Kresge, A. J. J. Org. Chem. 1979, 44, 1639-1642. doi:10.1021/jo01324a013
26. Ahmad, M.; Bergstrom, R. G.; Cashen, M. J.; Chiang, Y.; Kresge, A. J.; McClelland, R. A.; Powell, M. F. J. Am. Chem. Soc. 1979, 101, 2669-2677. doi:10.1021/ja00504a030

27. McClelland, R. A.; Ahmad, M.; Bohonek, J.; Gedge, S. Can. J. Chem. 1979, 57, 1531-1540. doi:10.1139/v79-250

28. Kirby, A. J. Stereoelectronic Effects; Oxford University Press, Incorporated, 1996.

29. Chandrasekhar, S.; Kirby, A.; Martin, R. J. Chem. Soc., Perkin Trans. 2 1983, 1619-1626. doi:10.1039/p29830001619

30. Freitas, M. P. Org. Biomol. Chem. 2013, 11, 2885-2890. doi:10.1039/c3ob40187a

31. Wipf, P.; Tsuchimoto, T.; Takahashi, H. Pure Appl. Chem. 1999, 71 , 415-421. doi:10.1351/pac199971030415

32. Allen, F. H. Acta Crystallogr., Sect. B 2002, 58, 380-388. doi:10.1107/S0108768102003890

33. Wo, S.; Zieger, H. E.; Millar, M. M.; Koch, S. A. J. Org. Chem. 1995, 60, 5925-5930. doi:10.1021/jo00123a032

34. Costello, J. F.; Draffin, W. N.; Paver, S. P. Tetrahedron 2005, 61, 6715-6719. doi:10.1016/j.tet.2005.05.014

35. Santry, L. J.; McClelland, R. A. J. Am. Chem. Soc. 1983, 105, 6138-6141. doi:10.1021/ja00357a027

36. Feng, L.-S.; Liu, M.-L.; Wang, S.; Chai, Y.; Lv, K.; Shan, G.-Z.; Cao, J.; Li, S.-J.; Guo, H.-Y. Tetrahedron 2011, 67, 8264-8270. doi:10.1016/j.tet.2011.08.089

37. Meerwein, H.; Borner, P.; Fuchs, O.; Sasse, H. J.; Schrodt, H.; Spille, J. Chem. Ber. 1956, 89, 2060-2079. doi:10.1002/cber.19560890907

38. Meerwein, H.; Bodenbenner, K.; Borner, P.; Kunert, F.; Müller, K. W.; Sasse, H. J.; Schrodt, H.; Spille, J. Angew. Chem. 1955, 67, 374-380. doi:10.1002/ange.19550671403

39. Risley, J. M.; Van Etten, R. L. J. Am. Chem. Soc. 1980, 102, 4609-4614. doi:10.1021/ja00534a007

40. Risley, J. M.; Van Etten, R. L. J. Am. Chem. Soc. 1979, 101, 252-253. doi:10.1021/ja00495a059

41. Bohé, L.; Crich, D. C. R. Chim. 2011, 14, 3-16. doi:10.1016/j.crci.2010.03.016

42. Yokoyama, Y.; Padias, A. B.; De Blauwe, F.; Hall, H. K., Jr. Macromolecules 1980, 13, 252-261. doi:10.1021/ma60074a010

43. Detz, R. J.; Abiri, Z.; le Griel, R.; Hiemstra, H.; van Maarseveen, J. H. Chemistry 2011, 17, 5921-5930. doi:10.1002/chem.201003727

44. Lapuka, L. F.; Chalova, O. B.; Kantor, E. A.; Kiladze, T. K.; Rakhmankulov, D. L. Chem. Heterocycl. Compd. 1981, 17, 876-879. doi:10.1007/BF00505587

45. Beringer, F.; Galton, S. J. Org. Chem. 1967, 32, 2630-2632. doi:10.1021/jo01283a602

46. Fukuda, H.; Hirota, M.; Endo, T. Tetrahedron Lett. 1986, 27 , 1587-1590. doi:10.1016/S0040-4039(00)84321-X

47. Newman, M. S.; Chen, C. H. J. Am. Chem. Soc. 1973, 95, 278-279. doi:10.1021/ja00782a068

48. Gallwey, F. B.; Hawkes, J. E.; Haycock, P.; Lewis, D. J. Chem. Soc., Perkin Trans. 2 1990, 1979-1985. doi:10.1039/p29900001979

49. Gaussian 09, Revision A. 1; Gaussian, Inc.: Wallingford, CT, 2009.

50. Becke, A. D. J. Chem. Phys. 1993, 98, 1372-1377. doi:10.1063/1.464304

51. Lee, C.; Yang, W.; Parr, R. G. Phys. Rev. B 1988, 37, 785-789. doi:10.1103/PhysRevB.37.785

52. Stephens, P. J.; Devlin, F. J.; Chabalowski, C. F.; Frisch, M. J. J. Phys. Chem. 1994, 98, 11623-11627. doi:10.1021/j100096a001 


\section{License and Terms}

This is an Open Access article under the terms of the Creative Commons Attribution License

(http://creativecommons.org/licenses/by/2.0), which permits unrestricted use, distribution, and reproduction in any medium, provided the original work is properly cited.

The license is subject to the Beilstein Journal of Organic Chemistry terms and conditions:

(http://www.beilstein-journals.org/bjoc)

The definitive version of this article is the electronic one which can be found at:

doi:10.3762/bjoc. 12.143 